\title{
AN ASSESSMENT OF THE Ambrosia L. POLLEN THREAT AT A REGIONAL SCALE USING THE EXAMPLE OF THE TOWN OF SOSNOWIEC (SILESIAN UPLANDS, POLAND)
}

\author{
${ }^{1}$ Kazimiera Chłopek, ${ }^{2}$ Katarzyna Dąbrowska-Zapart, ${ }^{3}$ Barbara Tokarska-Guzik
}

\author{
${ }^{1,2}$ Faculty of Earth Sciences, University of Silesia, Będzińska 60, 41-200 Sosnowiec, Poland, e-mail: kazimiera.chlopek@us.edu.pl, \\ ${ }^{3}$ Faculty of Biology and Environmental Protection, University of Silesia, Jagiellońska 28, 40-032 Katowice, Poland
}

Received: 05.03.2011

\begin{abstract}
The investigation of Ambrosia pollen counts in the air of Sosnowiec was carried out from 1998 to 2010 by means of the volumetric method. The pollen season which was determined by means of the $98 \%$ method started at the end of July and the beginning of August and lasted until the end of October. The highest Ambrosia pollen count was recorded in 1999 (222 grains $\left.\mathrm{x} \mathrm{m}^{-3}\right)$ and the lowest in $2001\left(18\right.$ grains $\left.\mathrm{x} \mathrm{m}^{-3}\right)$. It was stated that the daily count of pollen grains depended on the wind direction and maximum air temperature. The strongest correlations were found with maximum temperature and with a wind direction from the south east. A high negative correlation coefficient was found between the frequency of inflows of air masses from the west and the annual total of pollen grains and the value of the maximum daily count. The closest sites of Ambrosia L. are at a distance of 25-40 kilometres from the sampling point. Significant correlations with the frequency of inflow of air masses can support the conclusion that Ambrosia pollen grains recorded in Sosnowiec were most probably carried not only from local sources but also, at least in part, from distant places.
\end{abstract}

Key words: aerobiology, Ambrosia, pollen count, meteorological parameters, invasive plant, Sosnowiec Poland

\section{INTRODUCTION}

Ragweed pollen allergens cause severe allergies and they are counted among the most harmful in the world. In central and southern Europe, they are often a cause of allergic rhinitis and conjunctivitis (P e t e r $\mathrm{n}$ e 1 et al. 2008; Te s t $\mathrm{i}$ et al. 2009). In North America, they are the most frequent cause of pollinosis. Since the 1960s, ragweed pollen has been recorded in many European countries: France, northern Italy, southern Austria, the Czech Republic, Slovakia, the Balkan countries, Ukraine, and Hungary. An allergy to ragweed pollen allergens is considered to be a significant problem in the countries of central Europe (B o e h m e et al. 2009). In Poland, ragweed pollen has been recorded every year in the air of many cities since the 1990s (Kasprzyk, 1996; Malkiewicz and Wą sowicz, 2003; Weryszko-Chmielewska et al. 2003; Weryszko-Chmielewska, 2006; Lipiec et al. 2008; Rapiejko et al. 2009). The frequency of allergies to ragweed pollen allergens in Poland has not been thoroughly examined. In the Warsaw population, an increase in the frequency of positive skin tests with the ragweed pollen allergen has been observed, from $0.3 \%$ in 1998 to $1.5 \%$ in 2003 ( $\mathrm{R} \mathrm{a}$ piejko et al. 2006; Lipiec et al. 2008).

The Ambrosia genus of the composite family (Asteraceae) has 35-40 species (W illi s, 1973). They are anemophilous annual or perennial plants. Unisexual female flowers, which form pseudanthium inflorescences, appear in late summer or early autumn on shoot apices. Male flowers form leafless spikes or racemes in the upper, leafless part of a shoot. One stamen of a flower produces on average 3,375 pollen grains and one inflorescence $-16,875$. A plant with 20 racemes may release approximately 420 million pollen grains (Weryszko-Chmielewska and Piotrowska, 2008). The representatives of the Ambrosia genus are found in both the Americas and in Africa. In Europe, they appeared in the second half of the nineteenth century due to the import of corn, soya, clover, and also in ballast ( $\mathrm{S} \mathrm{chw}$ a r z, 1967). Since the Second World War, they have spread in many regions in southern and south-western Europe. Several species have spread beyond their natural range so widely that they have become cosmopolitan synanthropic plants (T a c i k, 1971). 


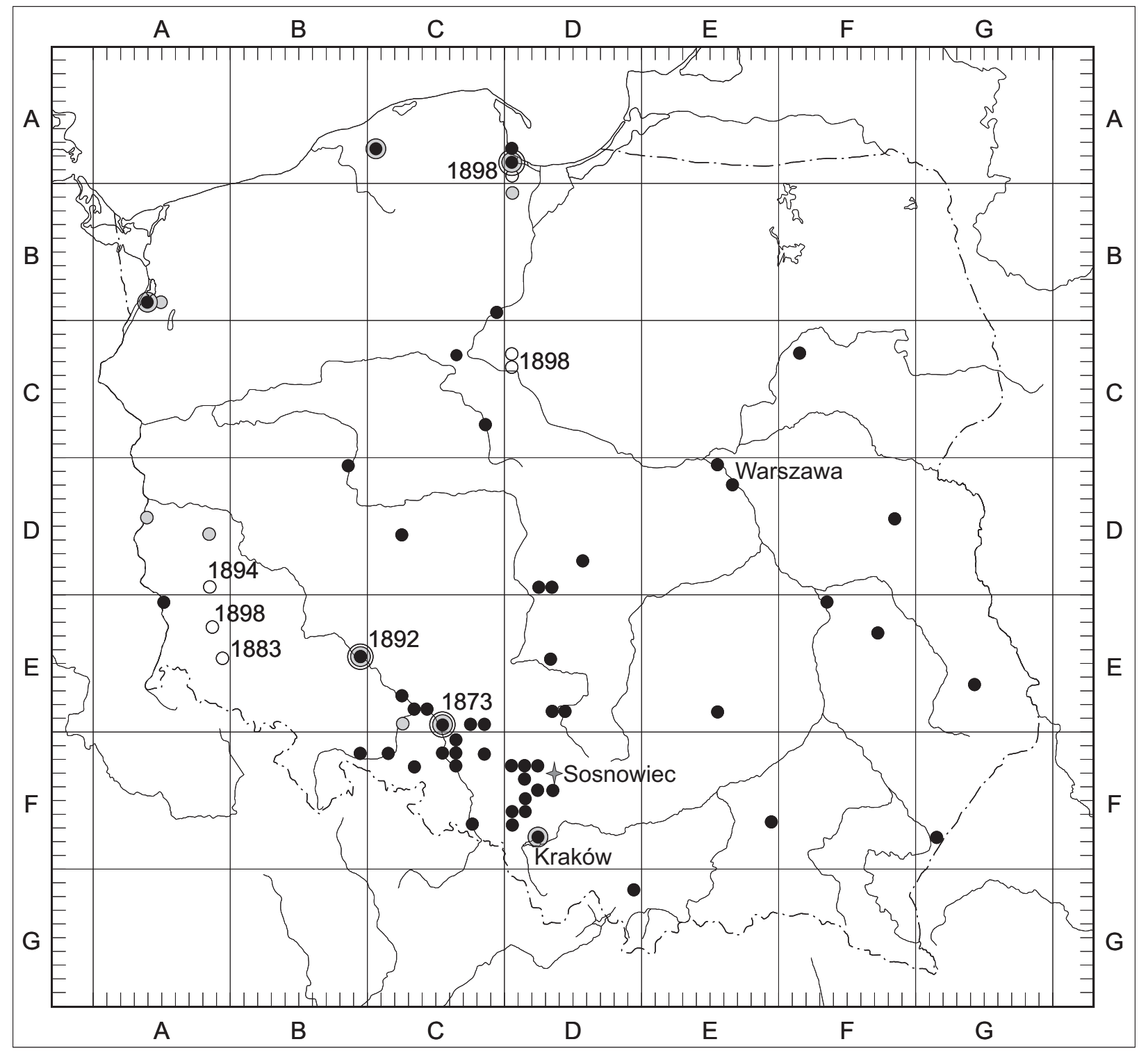

$\circ$ between 1851 and 1900

$\circ$ between 1901 and 1950

- between 1951 and 2009

Source: Tokarska-Guzik et al. 2011

Fig. 1. Recorded history of the spread of Ambrosia artemisiifolia L. in Poland drawn for the consecutive time periods.

In Poland, three species of the Ambrosia genus have been found so far: A. artemisiifolia L., A. psilostachya DC. = A. coronopifolia Torr. \& A. Gray and A. trifida L. (M i r e k et al. 2002). The first two species have the status of naturalized species in our country (Tokarska-Guzik, 2005; Zając et al. 1978), while A. trifida L. is treated as a casual species (M ir e k et al. 2002; R o s t a ń s ki and S ow a , 1986-1987). In Poland, the species most often found is Ambrosia artemisiifolia L. The first localities for this species were recorded in the second half of the nineteenth century in the western, south-western and northern part of the country. Currently, this species is scattered all over lowland Poland (T o k a r s k a - G u $\mathrm{z} \mathrm{i} \mathrm{k,} \mathrm{2001)} \mathrm{(Fig.} \mathrm{1).} \mathrm{In} \mathrm{the} \mathrm{region} \mathrm{of} \mathrm{Upper} \mathrm{Silesia,} \mathrm{the}$ first site of Ambrosia artemisiifolia was recorded in 1921 in Pszczyna (Li nd n e r 1921, herb. WRSL*). The next were recorded in Sosnowiec ( $\mathrm{S}$ ow a and Wójcik, 1969; M a jcher 1974, herb. LBL*), Tarnowskie Góry (S e n d e k, 1971, 1973; T o k a r ska-Guzik, 1999 unpublished data), Pyskowice (Michalak and Sendek, 1974-1975) Katowice - Stary Panewnik (B ołd y s , 1978, unpublished data), Zabrze - Biskupice (Sendek, 1984), Katowice 
- Kokociniec (Tokarska-Guzik 2000, herb. KTU*) and - outside the Katowice conurbation - in Częstochowa (Michalak and Sendek, 19741975; Pi a s e cki 1986, unpublished data). Currently, new localities of ragweed have been found along the national road between Katowice and Cieszyn at a distance of approximately 25-40 kilometres SW from the sampling point (see Materials and Methods) and one locality has been confirmed on a railway siding in Tarnowskie Góry at a distance of approximately 25 kilometres NW from the sampling point (Fig. 2).

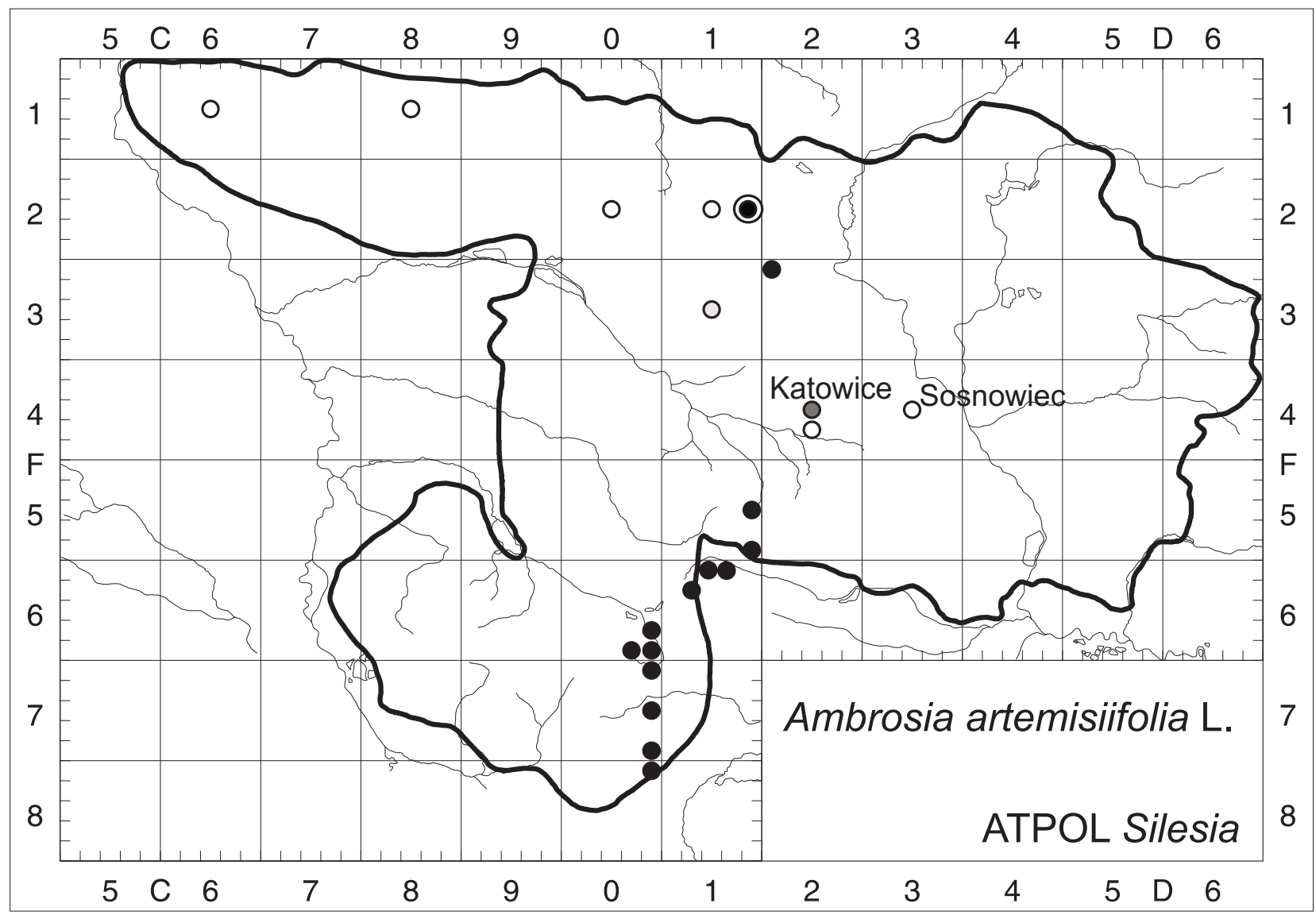

O between 1970 - 1980

O between $1981-1990$

- between 1991 - 2000

- recently recorded stations - 2007-2010

O confirmed stations

Source: Tokarska-Guzik et al. 2011

Fig. 2. Recorded history of the spread of Ambrosia artemisiifolia L. in the Silesian Uplands drawn for the consecutive time periods.

Ambrosia psilostachya is a species less frequently recorded. It was brought to Europe a little later. The first records come from Poland in 1901 (T o k a r s k a G u z i k, 2005) and from Great Britain in 1903 (S t a c e, 1997). By 2000 it was recorded in between ten and twenty scattered places ( Tokarska-Guzik, 2001). However, it is expanding only locally. The only site of this species in the region of the Katowice conurbation was recorded in Chorzów (S e n d e k, 1973; S e ndek 1971, herb. MGS*).
The aim of the present study was to assess the threat of ragweed pollen on local and regional scales. The paper contains an analysis of ragweed pollen seasons in Sosnowiec (southern Poland) on the basis of data from 1998 to 2010. Additionally, the impact of selected meteorological parameters on this pollen count was examined.

* Abbreviations for herbarium materials are explained in the Materials and Methods chapter 


\section{MATERIALS AND METHODS}

The Ambrosia L. pollen count data come from pollen monitoring in 1998-2010. The pollen count in the air of Sosnowiec was measured by means of the volumetric method using a Burkard spore trap (Hirsttype). The beginning and the end of the pollen season was determined by means of the $98 \%$ method. To compare the pollen counts over the studied years, a Seasonal Pollen Index (SPI) was calculated as the sum of the daily pollen counts in a given season. The sampling point is located in a district of Sosnowiec with wellspaced blocks of flats. The spore trap is at a height of approximately 20 metres above the ground level on the premises of the Faculty of Earth Sciences at the University of Silesia (263 metres above sea level, 50 $0^{\circ} 17^{\prime}$ 50 'N and $\left.19^{\circ} 08^{\prime} 20^{\prime \prime} \mathrm{E}\right)$. Meteorological data were delivered by a weather station which is about $20 \mathrm{~m}$ from the sampling point.

In the Silesian Uplands area, where Sosnowiec is situated, the influences of various air masses interact, therefore the climate is characterized by quite considerable variability and irregularity in the course of climatic elements. Sosnowiec is situated in a temperate climate zone - it has a climate transitional between oceanic and continental. On the majority of days throughout the year (63.5\%) the weather in Sosnowiec is determined by polar maritime air ( $\mathrm{N}$ i e d ź w i e d ź , 2003). Average annual temperature is $8.1^{\circ} \mathrm{C}$. The warmest month is July $\left(17.2^{\circ} \mathrm{C}\right)$ and the coldest - January $\left(-1.2^{\circ} \mathrm{C}\right)$. The average annual precipitation is about 700 $\mathrm{mm}$. The dominant winds are westerly ones: NW, W and SW ( $\mathrm{Eu} \mathrm{pikasza}$ and Widaw ski, 2008).

The average daily values of air temperature, relative humidity, precipitation, insolation, wind speed and direction were taken into account to assess the impact of meteorological parameters on selected characteristics of the pollen seasons. Furthermore, the direction and type of atmospheric circulation were subjected to analysis (Niedźwie dź, 1981). The relationships between individual meteorological parameters and various characteristics of the pollen season in all years were determined by means of Spearman's rank correlation coefficient (S t a n i s z, 2007).

The data about the history of the appearance and further spread of the species of the Ambrosia genus in the Silesian Uplands area (especially A. artemisiifolia) come from original observations and all relevant published, unpublished and herbarium data obtained by other researchers (Tok a r ska-Guzik, 2005; Tokarska-Guzik et al. 2011). The unpublished materials sent to the database "Distribution Atlas of Vascular Plants in Poland - ATPOL" ( $\mathrm{Z} \mathrm{a} \mathrm{j} \mathrm{a} \mathrm{c} \mathrm{and}$ $\mathrm{Z}$ a j a c , 2001) by botanists from all over Poland and the data gathered on the basis of our own floristic surveys provided the most essential and the most exten- sive information about the distribution of the species. A detailed list of the sites of the species examined can be found in the database of the program which gathers information about the distribution of alien naturalized species, the so-called neophytes or kenophytes (ATPOL-KENO). The program is an integral part of the national database of ATPOL. A map of the distribution of A. artemisiifolia in Poland was published in "Distribution Atlas of Vascular Plants in Poland" (T o k a r ska-Guzik, 2001). The map shown here contains further additions (Fig. 1). These data were gathered for the Silesian Uplands, as for the whole country, by means of the cartogram method (Fig. 2). However, in this case a square with a side of 2 kilometres was a basic unit (the data for Poland are gathered in squares with a side of 10 kilometres (Tokarska-Guzik et al. 2011; Zając, 1978; Zając and Zając, 2001).

* Acronyms for herbaria are given after M i r e k et al. (1997):

KTU - Department of Plant Systematics, University of Silesia

LBL - Department of Systematics and Phytogeography, Institute of Botany, Maria CurieSkłodowska University in Lublin

MGS - Upper Silesian Museum

WRSL - Museum of Natural History, University of Wrocław

\section{RESULTS}

The ragweed pollen season in Sosnowiec in 1998-2010 was extended from August to the middle of October. The pollen season started between $30^{\text {th }}$ June and $15^{\text {th }}$ August. Its onset was recorded earliest in 2007 $\left(30^{\text {th }}\right.$ June) and latest in 2005 ( $15^{\text {th }}$ August). The length of pollen seasons ranged from 41 days in 2008 to 103 days in 2007 (Table 1). The average length of pollen seasons was 63 days.

The Spearman's rank correlation between meteorological parameters and the length of pollen seasons showed a positive correlation between the level of precipitation and the length of the ragweed pollen season (Table 2). There were also significant positive correlations between the length of the pollen season and the number of days with a stationary front and with occurrences of polar maritime transformed air masses (Table 3).

The course of the ragweed pollen seasons varied over the studied years. An analysis of dynamic curves showed that the presence of pollen in the air of Sosnowiec was discontinuous. There were several-day breaks between days with the presence of pollen. The period of concentrated pollen release and the highest pollen counts covered various time ranges. The maximum pollen counts were in the last ten days of August 
or in the first half of September. The daily maximum was recorded earliest in 2000 (19 $9^{\text {th }}$ August) and as late as on $20^{\text {th }}$ September in 2001 (Table 1). The maximum difference between the years was thus 32 days.

The values of maximum daily pollen counts varied in different years and ranged from 18 to 222 grains $\mathrm{x} \mathrm{m}^{-3}$ (Fig. 3). The average daily count in the 12 years examined was 83 grains $\mathrm{x} \mathrm{m}^{-3}$. During the 1998-2010 pollen seasons, on the majority of days the ragweed pollen count was low, not exceeding 20 grains $\mathrm{x} \mathrm{m}^{-3}$. High counts were recorded only on single days. The highest daily pollen count was recorded in 1999 and the lowest in 2001 (Table 1). A daily maximum exceeding 100 grains $\mathrm{x} \mathrm{m}^{-3}$ happened only three times - in 1999 , 2002, and 2005 (Fig. 3). An analysis of daily variability in the ragweed pollen count from 2003 to 2010 showed that the highest pollen counts were between 11 p.m. and 9 a.m. (Fig. 4), except in 2003, when the highest counts were between 12 a.m. and 3 p.m..

A statistical analysis showed that the daily ragweed pollen count depended on the wind direction the higher counts were recorded when the prevailing winds were from the south, east and south-east (Table 4). Maximum air temperature turned out to be the most important among other meteorological parameters. It had a positive impact on the pollen counts (Table 5). The highest negative correlations were found with wind from the west and with the relative humidity of the air. It is important to add here that in spite of the high level of significance $(\alpha<0.001)$ the values of the correlation coefficients are very low.
Air masses coming from the west had a negative impact on the maximum values of pollen (Table 6). Concerning the types of air masses, a negative correlation was found with the frequency of days with an inflow of fresh polar maritime air and with the frequency of days with a cold front (Table 7).

The sum of the daily pollen counts in the whole ragweed pollen season (the Seasonal Pollen Index) varied from year to year (Fig. 5). It ranged from 114 grains in 2001 to 950 grains in 1999. A high Seasonal Pollen Index was also recorded in 2002, 2004 and 2008, but all were little more than half of the value obtained in 1999 (Table 1). The average annual sum in the 12 studied years was 352 grains. Air masses coming from the west had a negative impact on the annual sums of the pollen grains (Table 8). The ragweed pollen season in 1999 (the highest SPI) was characterized by a low rate of air mass inflows from the west. In this year, the highest number of days with a warm front, comparing all years, was noted as well as high temperature and high insolation were also recorded.

The results concerning the influence of wind direction and the impact of air masses are reflected in the distribution of A. artemisiifolia in the Silesian Uplands area. The sites of the species are still rare and scattered (Fig. 1 and 2). However, it is worth noting that a few new sites of this species have been found in recent years. They are situated along the road CieszynKatowice running to the south (K o s z e l a et al. 2009; Tokarska-Guzik et al. 2011; TokarskaGuzik 2007, herb. KTU).

Table 1.

Characteristics of Ambrosia pollen seasons in Sosnowiec, 1998-2010

\begin{tabular}{cccccc}
\hline Year & $\begin{array}{c}\text { Period of pollen } \\
\text { occurrence }\end{array}$ & $\begin{array}{c}\text { Length of pollen } \\
\text { season (days) }\end{array}$ & $\begin{array}{c}\text { Pollen grain concentration } \\
\text { on a peak day }\end{array}$ & Peak day & $\begin{array}{c}\text { Annual total } \\
\text { pollen grains }\end{array}$ \\
\hline 1998 & $2.08-26.09$ & 56 & 63 & 12.09 & 213 \\
1999 & $8.08-29.09$ & 52 & 222 & 4.09 & 950 \\
2000 & $22.07-1.10$ & 71 & 75 & 20.09 & 356 \\
2001 & $8.08-10.10$ & 63 & 18 & 4.09 & 114 \\
2002 & $27.07-30.09$ & 65 & 127 & 29.08 & 474 \\
2003 & $27.07-28.09$ & 63 & 59 & 30.08 & 215 \\
2004 & $11.08-4.10$ & 54 & 79 & 7.09 & 462 \\
2005 & $17.08-8.10$ & 52 & 114 & 24.08 & 390 \\
2006 & $12.08-17.10$ & 66 & 48 & 23.08 & 348 \\
2007 & $30.06-11.10$ & 103 & 40 & 6.09 & 156 \\
2008 & $5.08-15.09$ & 41 & 82 & 26.08 & 448 \\
2009 & $27.07-22.10$ & 87 & 61 & 24.08 & 267 \\
2010 & $3.08-24.09$ & 52 & 90 & 1.09 & 185 \\
\hline Average & $1.08-3.10$ & 63 & 83 & 352 \\
\hline
\end{tabular}


Table 2.

Spearman's correlation between the length of the pollen season and the meteorological parameters in 1998-2010

\begin{tabular}{|c|c|c|c|c|c|c|c|c|}
\hline \multicolumn{4}{|c|}{ Temperature $\left({ }^{\circ} \mathrm{C}\right)$} & \multirow{2}{*}{$\begin{array}{l}\text { Rainfall } \\
(\mathrm{mm})\end{array}$} & \multirow{2}{*}{$\begin{array}{l}\text { Humidity } \\
(\%)\end{array}$} & \multirow{2}{*}{$\begin{array}{l}\text { Insolation } \\
\text { (h) }\end{array}$} & \multirow{2}{*}{$\begin{array}{l}\text { Average wind } \\
\text { speed }(\mathrm{m} / \mathrm{s})\end{array}$} & \multirow{2}{*}{$\begin{array}{l}\text { Max. wind } \\
\text { speed }(\mathrm{m} / \mathrm{s})\end{array}$} \\
\hline medium & minimum & maximum & $\begin{array}{l}\text { above ground } \\
\text { level }(5 \mathrm{~cm})\end{array}$ & & & & & \\
\hline-0.30 & -0.14 & -0.37 & 0.05 & $0.69^{*}$ & 0.12 & $-0.63^{*}$ & 0.10 & 0.01 \\
\hline
\end{tabular}

$* * \alpha<0.001 ; * \alpha<0.05$

Table 3.

Spearman's correlation between the types of air masses and weather fronts and the length of the pollen season in 1998-2010

\begin{tabular}{cccccccccccccc}
\hline PPms & PPmc & PPm & PPk & PA & PZ & rmp & z & c & o & rf & st & - \\
\hline $0.64^{*}$ & -0.03 & 0.38 & 0.21 & -0.54 & 0.06 & 0.28 & 0.39 & -0.52 & -0.02 & -0.04 & $0.66^{*}$ & -0.34 \\
\hline
\end{tabular}

$* * \alpha<0.001 ; * \alpha<0.05$

$P P m s$ polar maritime old (transformed) air masses; PPmc polar maritime warm; PPm polar maritime fresh; $P A$ arctic air masses; $P P k$ polar continental; $P Z$ tropical air masses; $r m p$ various air masses; $z$ cold front; $c$ warm front; $o$ occlusion front; $r f$ various fronts; st stationary front; - no front

Table 4.

Spearman's correlation between the daily pollen counts and the wind direction in 1998-2010

\begin{tabular}{ccccccccc}
\hline $\mathrm{N}$ & $\mathrm{NE}$ & $\mathrm{E}$ & $\mathrm{SE}$ & $\mathrm{S}$ & $\mathrm{SW}$ & $\mathrm{W}$ & $\mathrm{NW}$ & $\mathrm{C}$ \\
\hline$-0.11^{*}$ & 0.02 & $0.20^{* *}$ & $0.33^{* *}$ & $0.23^{* *}$ & -0.03 & $-0.22^{* *}$ & $-0.19^{* *}$ & $0.16^{* *}$ \\
\hline$* * \alpha<0.001 ;{ }^{*} \alpha<0.05$ & & & & & & & &
\end{tabular}

Table 5 .

Spearman's correlation between the daily pollen counts and the meteorological parameters in 1998-2010

\begin{tabular}{ccccccccc}
\hline \multicolumn{3}{c}{ Temperature $\left({ }^{\circ} \mathrm{C}\right)$} & & Rainfall \\
medium & minimum & maximum & $\begin{array}{c}\text { Humidity } \\
\text { above ground } \\
(\text { level } 5 \mathrm{~cm})\end{array}$ & $\begin{array}{c}\text { Insolation } \\
(\mathrm{mm})\end{array}$ & $\begin{array}{c}\text { Average wind } \\
\text { speed }(\mathrm{m} / \mathrm{s})\end{array}$ & $\begin{array}{c}\text { Max. wind } \\
\text { speed }(\mathrm{m} / \mathrm{s})\end{array}$ \\
\hline $0.21^{* *}$ & 0.08 & $0.27^{* *}$ & -0.02 & $-0.14^{* *}$ & $-0.21^{* *}$ & $0.21^{* *}$ & $-0.09^{*}$ & $-0.09^{\star}$ \\
\hline
\end{tabular}

$* * \alpha<0.001 ; * \alpha<0.05$

Table 6.

Spearman's correlation between the directions of air masses and the maximum count of pollen grains in 1998-2010

\begin{tabular}{ccccccccccc}
\hline $\mathrm{N}$ & $\mathrm{NE}$ & $\mathrm{E}$ & $\mathrm{SE}$ & $\mathrm{S}$ & $\mathrm{SW}$ & $\mathrm{W}$ & $\mathrm{NW}$ & $\mathrm{v}$ & $\mathrm{x}$ \\
\hline-0.06 & 0.52 & 0.43 & 0.56 & -0.18 & 0.05 & $-0.78^{*}$ & -0.25 & -0.35 & 0.32 \\
\hline
\end{tabular}

$* * \alpha<0.001 ; * \alpha<0.05$

$v$ variable wind direction; $x$ unclassified situations

Table 7.

Spearman's correlation between the types of air masses and weather fronts and the maximum count of pollen grains in 1998-2010

\begin{tabular}{cccccccccccccc}
\hline PPms & PPmc & PPm & PPk & PA & PZ & rmp & z & c & o & rf & st & - \\
\hline-0.36 & -0.30 & $-0.72^{\star}$ & 0.58 & 0.55 & 0.01 & 0.22 & $-0.64^{*}$ & 0.19 & -0.27 & -0.24 & -0.36 & $0.64^{\star}$ \\
\hline
\end{tabular}

$* * \alpha<0,001 ; * \alpha<0,05$

PPms polar maritime old (transformed) air masses; PPmc polar maritime warm; PPm polar maritime fresh; PA arctic air masses; PPk polar continental; PZ tropical air masses; rmp various air masses; $z$ cold front; $c$ warm front; o occlusion front; rf various fronts; st stationary front; - no front 
Table 8 .

Spearman's correlation between the directions of air masses and the annual total of pollen grains in 1998-2010

\begin{tabular}{ccccccccccc}
\hline $\mathrm{N}$ & $\mathrm{NE}$ & $\mathrm{E}$ & $\mathrm{SE}$ & $\mathrm{S}$ & $\mathrm{SW}$ & $\mathrm{W}$ & $\mathrm{NW}$ & $\mathrm{v}$ & $\mathrm{x}$ \\
\hline 0.02 & 0.36 & 0.39 & 0.43 & -0.19 & 0.16 & $-0.82^{*}$ & -0.19 & -0.27 & 0.18 \\
\hline
\end{tabular}

$* * \alpha<0,001 ; * \alpha<0,05$

$v$ variable wind direction; $x$ unclassified situations

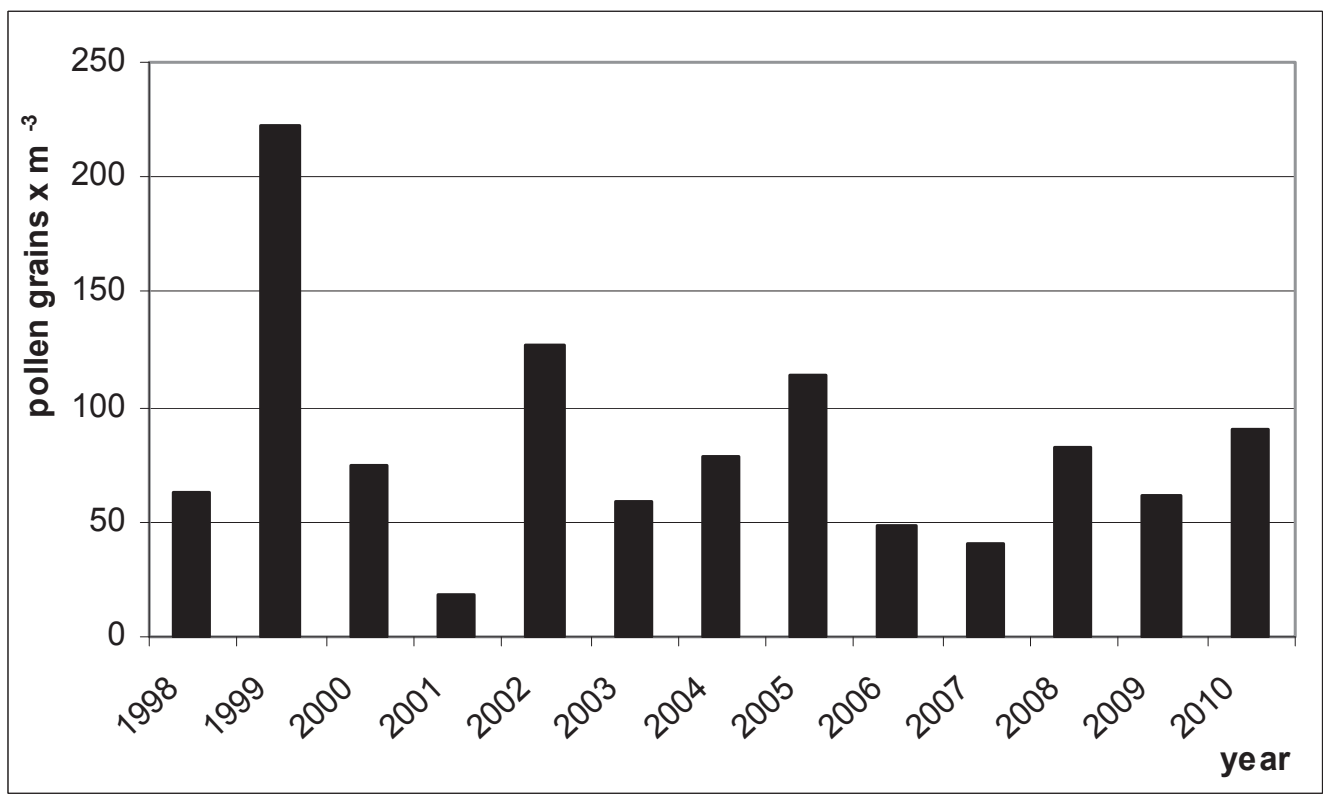

Fig. 3. The maximum count of pollen grains in 1998-2010.

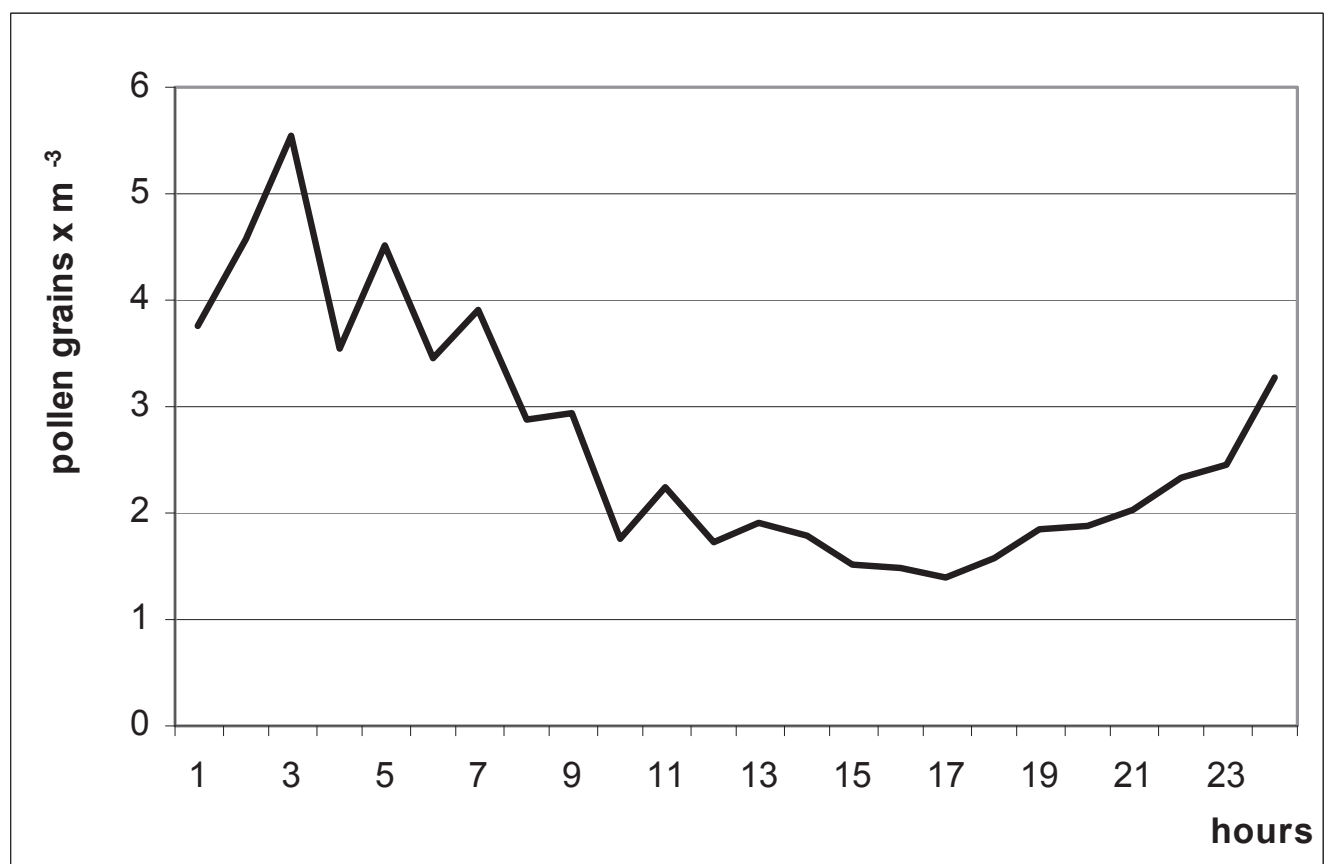

Fig. 4. Concentration of ragweed pollen grains per day (average of 1998-2010). 


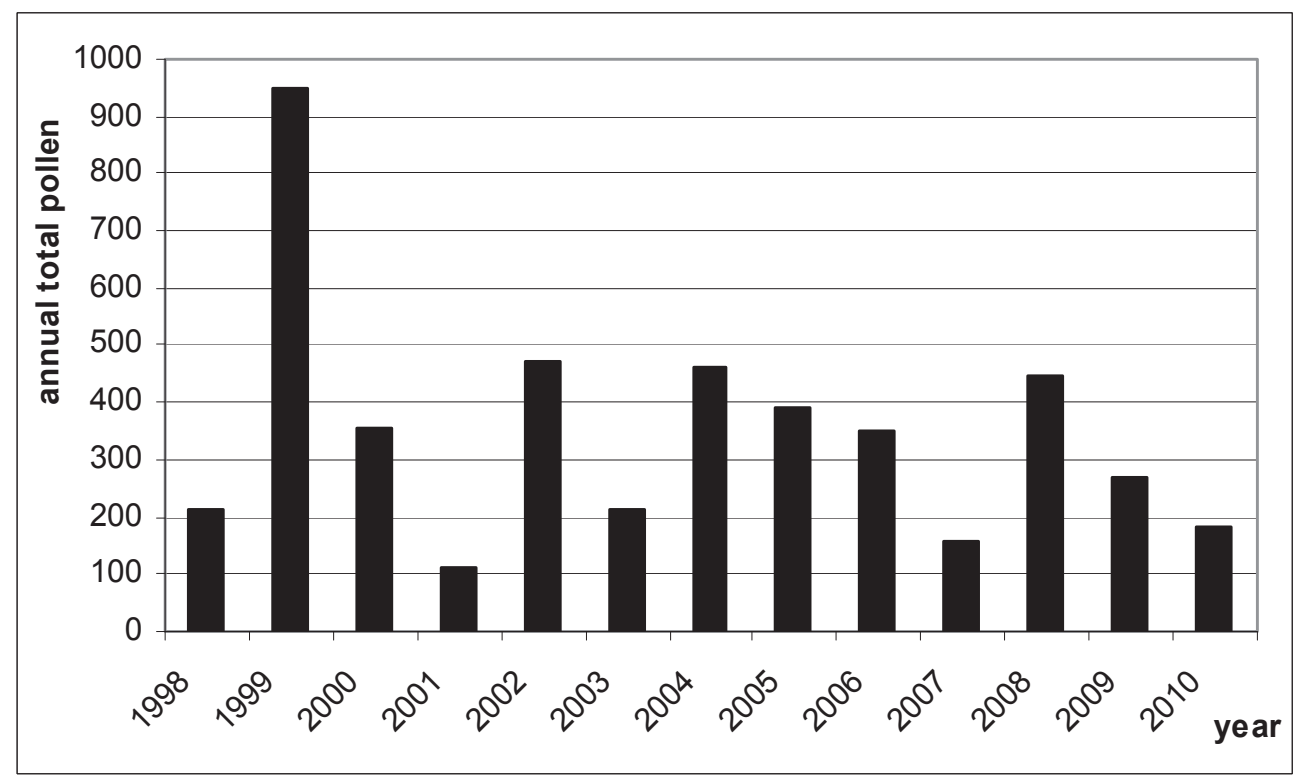

Fig. 5. The Seasonal Pollen Index in 1998-2010.

\section{DISCUSSION}

The observations of ragweed pollen in the air of Sosnowiec performed over a period of twelve years show variation in the onset and length of the pollen season and also fluctuations in the pollen counts.

The studies performed in many countries where ragweed is prevalent have shown a relationship between the aerial pollen count for this species and meteorological parameters, especially with regard to temperature, precipitation, and humidity ( $\mathrm{L}$ a a i d i et al. 2003; Makra et al. 2004; Peternal et al. 2005; Piotrowska and Weryszko-Chmielewska, 2006; P u c, 2004, 2006; S t a ch etal.2000; S tark, 1997; S tę p a ls k a et al. 2002). In the present investigation, only certain meteorological factors showed a statistically significant relationship with the pollen count. In all cases, the values of the correlation coefficients were low in spite of the high level of significance. With regard to the daily count, the meteorological parameters had a limited impact on the fluctuations of ragweed pollen concentrations in the air. The strongest correlations were found with maximum temperature and with the wind direction from the south and south east. Similar relationships for ragweed pollen in Rzeszów were found by K a s p r z y k (1996). In almost all the years, it was observed that the highest pollen counts occurred when air maximum temperature was above $25^{\circ} \mathrm{C}$, which was also found in Szczecin $(\mathrm{P} \mathrm{u} \mathrm{c}$, 2004, 2006). However, in Lublin the highest concentrations of pollen were observed when maximum temperature exceeded $21^{\circ} \mathrm{C}(\mathrm{Piotrowska}$ and $\mathrm{We}$ ryszko-Chmielewska, 2006).

Higher correlation coefficients, but with lower relevance, were obtained analyzing other characteri- stics of the ragweed pollen season. A high negative correlation coefficient between the frequency of inflows of air masses from the west and the value of the annual sum of pollen grains and the value of the maximum daily count was found. Polar maritime air masses had an impact on the duration of the ragweed pollen season and the maximum daily count. When there was an inflow of this type of air, the pollen seasons were longer and the seasonal maxima lower. The polar maritime air arrives in Poland from the west, from over the northern part of the Atlantic Ocean and therefore it is characterized by considerable humidity. In summer, it brings cold weather and cumulus clouds with thunderstorms. Furthermore, this would explain the positive correlation of rainfall with the length of the pollen season. Longer seasons were also found in the years when there were many days with a stationary front, which is not moving or is moving with a speed lower than $2 \mathrm{~m} \mathrm{x} \mathrm{s}^{-1}$.

A ragweed pollen grain is small and has good buoyancy characteristics. It can be carried by the wind over long distances. The closest certain sites of $\mathrm{Am}$ brosia L. are at a distance of 25-40 kilometres from the sampling point, which could be evidence that the pollen comes not only from local sources, but is also carried from distant places. It cannot be excluded that the pollen arrives from the Czech Republic, Slovakia, Ukraine and Hungary. Significant correlations with the frequency of inflow of air masses do confirm that the ragweed pollen grains recorded in Sosnowiec were most probably carried from distant places. An increase in maximum counts on the days when the wind from the south and south-east was predominant also suggests that the pollen is being carried from distant places. Cecchi (2007) considered it possible that pollen is carried together with moving air masses from 
Hungary to the central part of Italy. The fact that the highest pollen counts in Sosnowiec were recorded at night and in the morning also suggests that the pollen is being carried from distant places. In Poznań (S t a c h et al. 2000, 2007), Rzeszów (K a s przy k, 2008), and Lublin (Piotrowska and Werys zko-Chmielewska, 2006), ragweed pollen was also recorded at night and early in the morning. However, in Hungary (V i tán y i et al. 2003) and Croatia (P e t e rn e l et al. 2005), where ragweed grows abundantly, the daily maxima were recorded at midday. Also in France, the presence of pollen was found in the morning (9-11 a.m.) ( $\mathrm{L}$ a a i d $\mathrm{i}$ et al. 2003). In Poland, high pollen counts are recorded in Lublin every year, although ragweed sites have not been found. This may confirm the fact that the pollen is carried from distant places, in this case from Ukraine (P i o trow ska and Weryszko-Chmielewska, 2006), although new localities of $A$. artemisiifolia have been recorded in the Lublin region recently (personal inf. by F. Święs), mainly along railways.

The plant pollen does not appear to pose a significant threat to the inhabitants of the region, probably due to the fact that the number of Artemisia artemisiifolia sites found in the region is still low. No increase in ragweed pollen counts in Sosnowiec was found over the monitored period. However, the fact that new sites of this species are found and the fact that there is a possibility of pollen inflow from other regions of Europe where this species already poses a serious threat make it necessary to regularly monitor ragweed pollen concentrations in the air and to control the spread of the species in the region.

\section{CONCLUSIONS}

1. The ragweed localities closest to Sosnowiec were found along the national road between Katowice and Cieszyn at a distance of approximately 25-40 kilometres SW from the sampling point and one locality was confirmed on a railway siding in Tarnowskie Góry at a distance of approximately $25 \mathrm{ki}$ lometres NW from the sampling point.

2. The impact of meteorological parameters on changes in pollen counts was weak. The highest positive correlation was found between maximum temperature and the wind direction from the south, east and southeast, and the daily concentration of ragweed pollen.

3. A high negative correlation was found between the frequency of the inflow of air masses from the west and the maximum concentration and SPI for ragweed pollen.

4. The highest pollen counts were recorded mostly at night and early in the morning, which suggests that pollen comes from long transport, not only from local sources.

\section{REFERENCES}

Boehme M.W., Gabrio T., Dierkesmann R., Felder-Kennel A., Flicker-Klein A., Joggerst B., Kersting G., König M., Link B., Meisner V., Wetzig J., Weidner U., Behrendt H., 2009. Sensitization to airborne ragweed pollen - a cause of allergic respiratory diseases in Germany? Deutsche Medizinische Wochenschrift, 134(28-29): 1457-63.

Cecchi L., Torrigiani Malaspinn T., Albertini R., Zanca M., Ridolo E., Usberti I., Morabito M., Dall' Aglio P., Orlandi$\mathrm{ni}$ S., 2007. The contribution of long-distance transport to the presence of Ambrosia pollen in central northern Italy. Aerobiologia, 23: 145-151.

K a s p r z y k I ., 1996. Palynological analysis of airborne pollen fall in Ostrowiec Świętokrzyski in 1995. Ann. Agric. Environ. Med. 3: 83-86.

Kasprzyk I., 2008. Non-native Ambrosia pollen in the atmosphere of Rzeszów (SE Poland); evaluation of the effect of weather conditions on daily concentrations and starting dates of the pollen season. Int. J. Biometeorol. 52: 341-351.

Koszela K., Tokarska-Guzik B., Bzdęga K., Kulak-Książczyk S., Książczyk T.,2007 Ambrosia artemisiifolia L. in Poland: State-of-the-art studies and problem of risk assessment. CABI EuropeSwitzerland.

Laaidi M., Thibaudon M., Besancenot J.P., 2003. Two statistical approaches to forecasting the start and duration of the pollen season of Ambrosia in the area of Lyon (France). Int. J. Biometeorol. 48: 65-73.

Lipiec A., Weryszko-Chmielewska E., Piotrowska K., Malkiewicz M., Chłopek K., Puc M., Siergiejko Z., ZielnikJurkiewicz B., Rapiejko A., Modrzyński M., Ratajczak J., 2008. Analiza stężenia pyłku ambrozji w wybranych miastach Polski w roku 2007. / The analysis of ragweed pollen count in selected Polish cites in 2007. Alergoprofil, 4(1): 49-54. (in Polish)

Łupikasza E., Widawski A., 2008. Warunki klimatyczne obszaru Górnośląskiego Związku Metropolitalnego. / Climatic conditions of the Metropolitan Association of the Upper Silesia area. Polskie Towarzystwo Geograficzne Oddział Katowicki, 90-104. (in Polish)

Makra L., Juhász M., Borsos E., Béczi R., 2004. Meteorological variables connected with airborne ragweed pollen in Southern Hungary. Int. J. Biometeorol. 49: 31-41.

Malkiewicz M., Wąs owicz A.,2003. Ambrosia pollen grains in aeroplankton of Wrocław. Ann. Univ. Mariae Curie-Skłodowska. Sect. Hortic. EEE, 13: 333-339.

Michalak S., Sendek A., 1974-1975. Interesujące gatunki synantropijne $\mathrm{z}$ terenu województwa katowickiego. / Interesting species of synanthropic plants in the Katowice voivodeship. Zesz. Przyr. OTPN, 14-15: 1-10. (in Polish) 
Mirek Z., Musiał L., Wójcicki J.J., 1997. Polish herbaria. Polish Botanical Studies. Guidebook Serie, 18: $1-116$.

Mirek Z., Piękoś-Mirek H., Zając A., Zając M., 2002. Vascular plants of Poland. A Checklist. /Krytyczna lista roślin naczyniowych Polski. W. Szafer Institute of Botany, Polish Academy of Science. Kraków.

Niedźwiedź T., 1981. Sytuacje synoptyczne i ich wpływ na zróżnicowanie wybranych elementów klimatu w dorzeczu górnej Wisły. / Synoptic situations and their influence on the differentiation of selected climatic elements in the upper Vistula Basin. Rozprawy habilitacyjne Uniwersytet Jagielloński, 58. Kraków. (in Polish)

Niedźwiedź T., 2003. Częstość występowania mas powietrznych $\mathrm{w}$ Polsce południowej w drugiej połowie XX wieku. / The frequency of air masses in southern Poland in the second half the 20th century. Prace Geograficzne, 188: 65-74. (in Polish)

Peternel R., Culig J., Srnec L., Mitic B., Vucusic I., Hgra I., 2005. Variation in ragweed (Ambrosia artemisiifolia L.) pollen concentration in central Croatia, 2002-2003. Ann. Agric. Environ. Med. 12: 11-16.

Peternel R., Music Milanovic S., Srnec L., 2008. Airborne ragweed (Ambrosia artemisiifolia L.) pollen content in the city of Zagreb and implications on pollen allergy. Ann. Agric. Environ. Med. 15(1): 125-30.

Piotrowska K., Weryszko-Chmielewska E., 2006. Ambrosia pollen in the air of Lublin, Poland. Aerobiologia, 22(2): 149-156.

Puc M., 2004. Ragweed pollen in the air of Szczecin. Ann. Agric. Environ. Med. 11: 53-57.

Puc M., 2006. Ragweed and mugwort pollen in Szczecin, Poland. Aerobiologia, 22: 67-78.

Rapiejko P., Malkiewicz M., Lipiec A., Weryszko-Chmielewska E., Piotrowska K., Cecherz K., Chłopek K., Puc M., Rapiejko A., Stankiewicz W., Siergiejko Z., Tarasiewicz A., 2006. Analiza stężenia pyłku ambrozji w wybranych miastach Polski w 2006r. / The analysis of Ragweed pollen count in selected Polish cites in 2005. Alergoprofil, 4(1): 49-54. (in Polish)

Rapiejko P., Lipiec A. Malkiewicz M., Świebodzka E., Adżman K., Ratajczak J., Modrzyński M., Jurkiewicz D., 2009. Pyłek ambrozji w powietrzu wybranych miast Polski w 2008 r. / Ragweed pollen in the air of selected Polish cites in 2008. Alergoprofil, 5(2): 70-72. (in Polish)

Rostański K., Sowa R., 1986-1987. Alfabetyczny wykaz efemerofitów Polski. / Alphabetical list of ephemerophytes of Poland. Fragm. Floristica et Geobot. Pol. 31-32(1-2): 151-204. (in Polish)

S c hw a r z Z ., 1967. Badania nad florą synantropijną Gdańska i okolicy. / A study on the synanthropic flora of Gdańsk and the neighbouring areas. Acta Biol. Med. Soc. Sc. Gedan. 11: 363-494. (in Polish)
Sendek A., 1971. Nowe stanowiska rzadkich gatunków roślin na Śląsku zebranych w latach 1968 i 1969. / New locations of rare species of plants in Silesia, collected in the years 1968 and 1969. Zesz. Przyr. OTPN, 11: 51-56. (in Polish)

S en dek A., 1973. Flora synantropijna stacji górnośląskiego węzła kolejowego. / Synanthropic flora at a station of an Upper Silesian railway junction. Zesz. Przyr. OTPN, 3: 3-21. (in Polish)

Sendek A., 1984. Rośliny naczyniowe Górnośląskiego Okręgu Przemysłowego. /Vascular plants of the Upper Silesia Industrial Region. Zesz. Przyr. OTPN, 1: 1-140. (in Polish)

Sowa R., Wójcik-Chrobok B., 1969. O niektórych interesujących roślinach synantropijnych zebranych na terenie Sosnowca. /About some interesting synanthropic plant species collected within the city of Sosnowiec. Zesz. Nauk. Univ. Łódź, 2(31): 51-67. (in Polish)

St ace C., 1997. New Flora of the British Isles. Second edition. Cambridge Univ. Press.

Stach A., Silny W., Operacz-Czarnecka M., 2000. Prawdopodobieństwo zagrożenia alergicznego pyłkiem Ambrosia. / Probability of allergic threat of Ambrosia pollen. Alergia, 3(6): 22-23. (in Polish)

Stach A., Smith M., Skjřth C.A., Brandt J., 2007. Examining Ambrosia pollen episodes at Poznań (Poland) using back-trajectory analysis. Int. J. Biometeorol. 51: 275-286.

Stark P.C., Ryan L.M., McDonald J.L., Burge H.A., 1997. Using meteorological data to predict daily ragweed pollen levels. Aerobiologia, 13: 177-184.

Stanisz A., 2007. Przystępny kurs statystyki z zastosowaniem STATISTICA Pl na przykładach z medycyny. Statsoft Polska, Kraków. (in Polish)

Stępalska D., Myszkowska D., Szczepanek K., 2002. Variation in Ambrosia pollen concentration in Southern and Central Poland in 1982-1999. Aerobiologia, $18,: 13-22$.

Tacik T., 1971. Ambrozja (Ambrosia L.). [In:] B. Pawłowski, A. Jasiewicz (eds). Flora Polska. Państwowe Wydawnictwo Naukowe, Warszawa - Kraków: 222-225. (in Polish)

Testi S., Carabelli A., Cecchi L., Giacomelli C., Iannello G., Rocchi V., Rossi O., Spadolini I., Vannucci F., Campi P., 2009. Multicenter investigation to assess the prevalence of Ambrosia pollen allergy in Tuscany. J Investig. Allergol. Clin. Immunol. 19(3): 251-2.

Tokarska-Guzik B., 2001. Ambrosia artemisiifolia L. and Ambrosia psilostachya DC. [In:] A. Zając, M. Zając (eds). Atlas rozmieszczenia roślin naczyniowych w Polsce. Laboratory of Computer Chorology, Institute of Botany, Jagiellonian University and Fundation of Jagiellonian University, Kraków. (in Polish)

Tokarska-Guzik B ., 2005. The establishment and spread of alien plant species (kenophytes) in the flora of Poland. Wyd. UŚ Katowice, 2372: 1-192. 
Tokarska-Guzik B., Bzdęga K., Koszela K., Żabińska I., Krzuś B., Sajan M., Sendek A., 2011. Allergenic invasive plant Ambrosia artemisiifolia in Poland: threat and selected aspects of biology. Biodiver. Res. Conserv. 21:

Vitányi B., Makra L., Juhász M., Boros E., Béczi R., Szentpéteri M., 2003. Ragweed pollen concentration in the function of meteorological elements In the south-eastern part of Hungary. Acta Climatol. Chorol., 36-37: 121-130.

Weryszko-Chmielewska E. (ed.). 2006. Pyłek roślin w aeroplanktonie różnych regionów Polski. / Plant pollen in aeroplankton of different regions of Poland. Wyd. Katedra i Zakład Farmakognozji AM Lublin. (in Polish)

Weryszko-Chmielewska E., Piotrowska K., Czarneć k y j M., 2003. Ambrosia and Iva pollen in the air of Lublin and Lviv. Ann. Univ. Mariae CurieSkłodowska. Sect. Hortic. EEE, 13: 341-349.

Weryszko-Chmielewska E., Piotrowska K., 2008. Ecological features of Ambrosia artemisiifolia L. flowers and characteristics of Ambrosia L. pollen seasons in the condition of Lublin (Poland) in the years 2001-2008. Acta Agrobot. 61(2): 35-47.

Will is J.C., 1973. A dictionary of the flowering plants and ferns. Eight edition. Cambridge Univ. Press.

Zając A., 1978. Atlas of distribution of vascular plants in Poland (ATPOL). Taxon, 27(56): 481-484.

Zając A., Zając M., 2001. (eds). Distribution Atlas of Vascular Plants in Poland. Laboratory of Computer Chorology, Institute of Botany, Jagiellonian University and Fundation of Jagiellonian University, Kraków.

\section{Ocena zagrożenia pyłkiem Ambrosia L. w skali regionalnej na przykładzie miasta Sosnowca (Wyżyna Śląska, Polska).}

\section{Streszczenie}

Badania koncentracji pyłku Ambrosia w powietrzu Sosnowca prowadzono w latach 1998-2010 metodą wolumetryczną. Początek sezonu pyłkowego Ambrosia, wyznaczony metodą $98 \%$, rozpoczynał się na przełomie lipca i sierpnia i trwał do końca października. Wysokie koncentracje pyłku notowano najczęściej w trzeciej dekadzie sierpnia lub w pierwszej połowie września. Najwyższe stężenie pyłku Ambrosia odnotowano w 1999 roku (222 ziarn x m³ ${ }^{-3}$, najniższe w 2001 roku (18 ziarn $\left.\mathrm{x} \mathrm{m}^{-3}\right)$. Wykazano, iż stężenie dobowe ziarn pyłku zależało od kierunku wiatru i temperatury maksymalnej powietrza. Najsilniejszą korelację stwierdzono dla temperatury maksymalnej i dla kierunku wiatru z południowego wschodu. Znaleziono wysoki ujemny współczynnik korelacji między częstością napływu mas powietrza z zachodu a wartością sumy rocznej ziarn pyłku oraz z wartością maksymalnego stężenia. Stwierdzono również oddziaływanie masy powietrza polarno-morskiego na długość sezonów pyłkowych i na wartości maksymalnego stężenia Ambrosia. Przy napływie tego typu powietrza notowano dłuższe sezony pyłkowe oraz niższe maksima sezonowe. Stanowiska z Ambrosia zostały stwierdzone w odległości $25-40 \mathrm{~km}$ na SW i NW od punktu pomiarowego. Istotne korelacje $\mathrm{z}$ częstością napływu mas powietrza mogą potwierdzać fakt, iż ziarna pyłku Ambrosia rejestrowane w Sosnowcu pochodzą nie tylko z lokalnych źródeł ale również z dalekiego transportu. 